\title{
Allying With The Plants: A Pedagogical Path Towards The Planthroposcene
}

\author{
Irida Tsevreni ${ }^{1 *}$
}

\author{
${ }^{1}$ Department of Early Childhood Education, University of Thessaly, GREECE \\ *Corresponding Author: itsevreni@uth.gr
}

Citation: Tsevreni, I. (2021). Allying with the plants: A pedagogical path towards the Planthroposcene. Interdisciplinary Journal of Environmental and Science Education, 17(4), e2249. https://doi.org/10.21601/ijese/10985

\begin{tabular}{ll}
\hline ARTICLE INFO & ABSTRACT \\
\hline Received: & $\begin{array}{l}\text { The notion of the Planthroposcene is based on an attempt to disconnect from the sustainability rhetoric } \\
\text { of the Anthropocene and to choose to overcome the ecological crisis through an ecocentric path. In the } \\
\text { current research, students of a Pedagogical Department at a University in Greece were encouraged to } \\
\text { investigate their relationship with plants, to ally with them and to reflect on their experience, } \\
\text { experimenting in an alternative way of empowering their ecological consciousness, away from the } \\
\text { Accepted: }\end{array}$ \\
$\begin{array}{l}\text { traditional environmental education practice based on sustainability. They designed and proposed } \\
\text { activities, exploring and strengthening their connection to plants. Their activities were implemented } \\
\text { through mindfulness techniques (meditation, yoga), art-based practices (drawing, dramatization, poem }\end{array}$ \\
$\begin{array}{l}\text { writing, dance) and taking action. The data analysis revealed that the students through their activities } \\
\text { practiced participatory observation, communication, sensorial and embodied experience with plants. } \\
\text { The manifestation of empathy for the otherness of plant-being also took place. }\end{array}$
\end{tabular}

Keywords: Planthroposcene, human-plant connection, ecocentrism, ecological consciousness, environmental education

\section{INTRODUCTION}

In the era of the Anthropocene, the Earth suffers from environmental destruction on a mass scale caused mainly by the establishment of human exceptionalism. Nowadays, we are called, now more than ever, to reconsider our choices and to make essential decisions for the recreation of an alternative world that we want to share with our human and more-than-human others. The environmental institutions worldwide have been insisted on anthropocentric solutions for the confrontation of the global ecological crisis that deify green economy and green technology in the framework of the sustainability rhetoric. However, the results of these choices have been nothing but optimistic. On the contrary, voices for the creation of a common, multispecies world have been raised by scholars, who vision an alternative, ecocentric world away from nature/culture dualism (e.g. Haraway, 2008; Latour, 2004; Tsing, 2012, 2015; Wolfe, 2010).

The current study is inspired by Myer's (2018) vision for a human-plant conspiracy towards the Planthroposcene, as well as by Abram's (1997) ecophenomenology and his suggestion that the new environmental ethic will take place not through the logical elucidation of new philosophical principles and legislative strictures, but through our embodied, sensorial empathy with the more-than-human world. Based on the above theoretical and ontological framework, the students of an environmental education course of the Department of Early Childhood Education, University of Thessaly in Greece were encouraged to investigate their connection to plants, to ally with them and to reflect on their experience.

They experimented in an alternative way on empowering their ecological consciousness, away from the established sustainability rhetoric and the anthropocentric environmental education practice. In this framework, different activities took place by the students, including discussions, experimentations, art and action, revealing the potential of an ecocentric pedagogical framework for a human-plant alliance. The research also emphasizes embodied, sensorial and liberating coexistence and synergy between human and more-than-human others. 


\section{The Potential of Human-Plants Synergy}

Nowadays, we experience the challenging endeavor of living in the geological era of the Anthropocene, in which human destructive activities have affected the stability and balance of the ecosystems through the symptoms of the ecological crisis: climate change, pollution, ecosystems' destruction, etc. (Crutzen, 2002). Recently, there have been suggestions that Capitalocene or Plantationocene are historically, socially and politically more appropriate terms than the Anthropocene. The Capitalocene "signifies capitalism as a way of organizing nature - as a multispecies, situated, capitalist world-ecology" (Moore, 2016, 6), since the Anthropocene ignores inequalities, imperialism, colonialism, capitalism, white supremacy and human exceptionalism (Myers, 2018). D. Haraway and A. Tsing have also proposed Plantationocene to call attention to the contribution of the plantation agriculture to the formation of the new geological and socioeconomic era that has been destructively transformed the planet and life on it (Mitman, 2019).

Looking beyond anthropocentrism, there is a diversity of voices within environmental movement, philosophy and ethics that propose an alternative, ecocentric path for the future of the planet. By ecocentrism, we mean what Sitka-Sage, Kopnina, Blenkinsop and Piersol (2018, p. 21) summarize as "an ethical view of 'nature' as having intrinsic value and perspectives beyond the human."

The alienation from nature and the need to reconnect with the natural world is not a new concept. Edward Osborne Wilson, the American biologist and naturalist, introduced the concept of biophilia - the instinctive bond between human beings and other living organisms and systems (Wilson, 1984). In order to confront the hyper-separation of human beings and nature (Plumwood, 2002), Orr (1994) emphasizes the need for a "biophilia revolution" towards equity, solidarity and affinity of all beings, human and morethan human (Abram, 1997; Haraway, 2016; Morton, 2017).

The ecocentric thought is also rooted in the approach of deep ecology of A. Naess, which emphasizes coexistence, empathy and solidarity with non-human creatures and questions the economical and technological development of the modern, western civilization and the evolution of our ecological self (Naess, 1998; Naess, Drengson, \& Devall, 2008). Ecological crisis has also an ontological perspective, as it represents a spiritual crisis, the crisis of human feeling and our whole mode of sensibility (Bonnett, 2007). Furthermore, the ecological crisis is a perceptual crisis, based on our sensory blindness towards nonhuman voices that coexist in the same world with us (Abram, 1997).

In the current study, we focus on the investigation of human-plants connection and alliance through an ecocentric gaze that has recently begun to emerge in the literature (e.g. Hall, 2011; Marder, 2013, 2014; Myers, 2015; Wohlleben \& Flanery, 2016). We cannot overlook the fact that our modern society is characterised by plantblindness - the inability to perceive the ultimate otherness of plant-being beyond the dominant cultural and scientific schemata, beyond the reflections of ourselves (Aloi, 2018).

In line with ecocentric research, Myers (2018), through her essay "How to grow livable worlds: Ten notso-easy steps", introduced as to the term and context of the "Planthroposcene", encouraging us to experiment with different ways of dreaming and to create alternative, livable worlds, as well as to learn other ways to see, feel and know through experimentation - a rather radical approach of the established science and art. Myers (2018) proposes a path created by "ten not-so-easy steps" for moving away from the Anthropocene and creating a livable world, in alliance with the plants.

The Planthroposcene includes an attempt to disconnect from the sustainability rhetoric based on the framework of colonialism and capitalism that create unlivable worlds in the Anthropocene, since there is no way to confront anthropocenic violence using Anthropocene logics. The greening of the economy, under the threat for the apocalyptic disaster of the planet, is not the answer to ecological crisis. Human exceptionalism and Man's independence in the Anthropocene do not help us realize that there are other forces and powers among us, beings with billions of years more experience than us, in creating livable worlds (Myers, 2018).

Our most powerful ally for the composition of livable worlds is the photosynthetic organisms - the plants. These green creatures are not only "the lungs of the earth", "they literally breathe us into being", but also "a kind of alchemical, cosmic mattering." They know how to create "livable, breathable, and nourishing worlds. As they exhale, they compose the atmosphere; as they decompose, they matter the compost and feed the soil. Holding the earth down and the sky up, they sing in nearly-audible ultrasonic frequencies as they transpire, moving massive volumes of water from the depths of the earth up to the highest clouds" (Myers, 2018, 2-3). So, we have to work with and for plants, to conspire with plants in order to make livable worlds that can nourish, cloth, feed, heal, shelter and pleasure us (Myers, 2018).

Myers (2018) proposes a conspiracy between people and plants. This approach includes getting on their side, considering ourselves at their service, getting to know plants and offering them the soils, space and time to flourish. Towards the creation of livable worlds in the Planthroposcene, we should move away from the effect of human exceptionalism, mechanistic science and capitalistic economy that defines our view of plants as property, resource, commodity or subject of anthropocentric scientific research. Since million years 
ago, until today, there are people who cultivate deep relationships with plants. In this alternative way of seeing and being with the world we should base our participation in livable worlds.

Vegetalization of our sensorium, in order to learn with and alongside the plants, is the next step. This approach, according to Myers (2018), includes getting interested in the things that plants care about, observing and making space for plants to grow, letting their sensibilities alter our perceptions and knowledge about sensing, sensitivity and sentience. Myers proposes the activation of our inter plant, through incantations, hypnosis, meditation or yoga, experimenting with vegetalization of our sensorium and experiencing new sensible worlds. She also suggests that we should practice ecology in a different way, away from its conventional form that reproduces the colonial and capitalist desires of this discipline. An ungridable ecology that refuses the colonialism, militarism, heteronormativity and economizations of life, metrics that would approach ecological relations as mechanical. In that way, a whole new world opens up that allows a different perception of the cosmos of plants world, which is alive and interactive and attempts to connect with us.

According to Myers $(2018,9)$ the main goal in the Planthroposcene "is to stage plant/people conspiracies to keep this planet livable and breathable." We should let the plants grow everywhere: to break through the concrete; to root into and surface; to grow through the holes in every fence. Away from an Edenic desire to control plants in an Anthropocenic city, the Planthroposcenic city will offer space to plants to grow everywhere. Finally, making alternative art for the Planthroposcene will contribute to the strengthening of human/plant connection. "Whatever you do, conspire to make art, like your life depends on disrupting with dissensus the colonial common sense that would leave us all to die in the Anthropocene" (Myers, 2018, 9).

\section{METHODOLOGY}

The research attempts to investigate the pedagogical implementation of Myers' vision of the Planthroposcene in the framework of environmental education. It explores if and how the notion of the Planthroposcene could be applied in pedagogical theory and praxis and which benefits students / future in-service teachers could can obtain that would help them design ecocentric environmental education programs.

The purpose of the current research is to share the findings of a project that took place in the framework of the an environmental education course entitled "empowering children-nature relationship" course at the Department of Early Childhood Education, University of Thessaly during the spring academic semesters of 201819 \& 2019-20. During these semesters, the undergraduate students of the specific course studied in groups Natasha Myers's essay "How to grow livable worlds: Ten not-so-easy steps".

Fifty (50) and thirty-nine (39) students participated in the project in the courses of 2019 and 2020, respectively. The students worked in groups of 4-7. They were encouraged to experiment with the content of the Planthroposcene hypothesis, choosing one or more of the proposed steps in order to investigate their connection to plants. They proposed, designed and experienced various activities. The groups shared their ideas, activities and actions with the class and reflected on their experience in a brief group report through the methodology of nature journaling (Tsevreni, 2021).

Ontologically and methodologically, this assignment was implemented in the framework of an experiential environmental education that attempts to move away from human exceptionalism and to conduct pedagogical research and praxis under the lens of ecocentrism (Tsevreni, 2021). It was also based on the basic principles of ecophenomenology that includes the empowerment of ecological consciousness through the embodied, sensorial experience of the more-than-human world (Abram, 1997)

The research explores how the idea of the Planthroposcene can integrate in the environmental education framework and contribute to the establishment of an ecocentric, ecological consciousness. Specifically, the paper attempts to answer the following research questions:

- How can the notion of the Planthroposcene can inspire and affect participants of an environmental education course?

- Can the notion of the Planthroposcene contribute to the obtainment of an ecocentric, ecological consciousness?

\section{Data Selection and Analysis}

The research draws upon students' feedback texts on their activities, allowing a deeper understanding of their perceptions and thoughts regarding their connection to plants. The data of the current study include students' activities, feedback texts and group interviews. The students' activities and reflection were recorded on their group nature journals, in which they described the activities that chose and performed. They were encouraged to accompany their descriptions with various forms of expression (e.g. photographs, drawings, poems). Furthermore, semi-structured interviews were implemented on selected group activities.

Data analysis took place using thematic analysis, as a flexible, qualitative method in two stages. Themes were identified within data, which were strongly linked to the data, in an inductive (bottom-up) way (Boyatzis, 1998; Braun \& Clarke, 2006). Initial codes and coding frames were compared and sorted, in order the final themes to be defined (Braun \& Clarke, 2006). 
The data were analyzed, emerging four themes that manifest the ways that students were inspired to connect with plants and to empower their ecological consciousness: a) participatory observation and communication with plants, b) sensorial and embodied experience of plants, c) manifestation of empathy for the world of plants using art-based techniques (drawing, dramatization, poem writing, dance) and mindfulness techniques (meditation, yoga), d) action.

\section{RESULTS}

The data analysis revealed that students, through their activities, practiced participatory observation, communication and sensorial experience with plants. The manifestation of empathy for the world of plants took also place through mindfulness (meditation, yoga) and art-based (drawing, dramatization, poem writing) techniques. Finally, there was one group of students that took action (Table 1).

\section{Participatory Observation and Communication with Plants}

The students observed closely various plants in their direct environment and reflected in their groups, sharing their thoughts and ideas regarding the plants' appearance in their everyday life. They noticed properties and qualities that they had not done before. Some of the students used observation as the first stage of familiarizing with the plants, in order to step to the next phase of sensory experience of plants, dramatization or vegetization of their senses.

A group of students chose to observe a plant for a period of one week and kept a journal of their observations and reflections. They documented their observations and thoughts regarding functions, such as plants' form, behaviour, movement and blooming, as well as issues like plants' care and human/plant communication. For example:

"Day 5: Today I had the need to interact with the natural world in a different way. I tried to approach (the plant) through a different way, since caring for it did not seem to be enough for me anymore. I needed to communicate with it. I

Table 1. Types of activities proposed and implemented by the students, inspired by the notion of the Planthroposcene

\begin{tabular}{|c|c|c|c|c|c|}
\hline \multirow[t]{2}{*}{$\begin{array}{l}\text { Group/ } \\
\text { Activity }\end{array}$} & \multirow{2}{*}{$\begin{array}{l}\text { Participatory } \\
\text { observation } \\
\text { and } \\
\text { communication } \\
\text { with plants }\end{array}$} & \multirow{2}{*}{$\begin{array}{l}\text { Sensorial and } \\
\text { embodied } \\
\text { experience } \\
\text { with plants }\end{array}$} & \multicolumn{2}{|c|}{$\begin{array}{l}\text { Manifestation of empathy for the world of } \\
\text { plants }\end{array}$} & \multirow[t]{2}{*}{$\begin{array}{l}\text { Taking action to ally } \\
\text { with plants }\end{array}$} \\
\hline & & & $\begin{array}{l}\text { Using art-based } \\
\text { techniques to } \\
\text { connect to plants }\end{array}$ & $\begin{array}{l}\text { Using mindfulness } \\
\text { techniques to } \\
\text { connect to plants }\end{array}$ & \\
\hline
\end{tabular}

2019 course

1

2

3

4

5

6

7

8

9

10

$$
1
$$

2

3

4

5

2020 course 
talked to it, saying "good morning". I told that I was all right and I asked the plant how it was. I touched it; I smelled it and I felt the breath of a living organism. I felt the significance of the essential communication with the natural world for the first time."

Another group chose to observe nature with appropriate equipment (magnifying glass, notebook, camera) and then to communicate with a specific plant. They shared their experience of communication and they ended up whispering their thoughts, messages and wishes to the plants.

The groups that chose to practise participatory observation and communication with plants achieved to pass from an anthropocentric, sciencebased and cognitive-centred model, that is very common in traditional environmental education programs, to an alternative way of coexistence with plants. This alternative way included devoting time to observe plants, not through the detached, anthropocentric way that usually includes plants' classification, measurement and segmentation. On the contrary, the plants were approached as whole living creatures. The students attempted to leave behind their anthropocentric view and to communicate with plants, talking and sharing their thoughts with them.

\section{Sensorial and Embodied Experience of Plants}

There were four groups of students that attempted to approach plants through their senses, especially through touch and smell, as well as through their bodies. These groups mentioned that they tried to leave the anthropocentric view and to approach plants with their bodies and its senses. For example, a group of students combined the sensorial, corporeal experience of plants with dramatization, experiencing the sensorial participation in the life of a tree:

\section{"... we touch the tree, we feel its aura and then we lower our body in a fetal position, representing the plant's seed. Gradually, we raise our body, feeling our feet sinking in the ground as the tree's routs and our body grows up as the trees' trunk. Our hands are moving like the branches of the tree seeking for the sun and our movements are leaded by the air as a tree's branches. We finally hug the trees, thanking them for this experience."}

The students proposed a sensorial, corporeal experience of the plants, away from the theoretical, detached, anthropocentric view that is common in traditional environmental education programs where plants are objects of scientific study for their benefits to human societies. Using their touch and smell, the students chose to follow an alternative path, that included a "carnal" interaction with the more-than-human world, away from cognitive, theoretical schemes.

\section{Manifestation of Empathy for the World of Plants}

The manifestation of empathy for the world of plants took place in most students' groups. The students attempted to take the role of plants and to operate as they do. They chose to use art-based and mindful techniques.

Art-Based Techniques. Nine groups of students used art-based techniques as a creative tool to enable them familiarizing and communicating with plants. They used dramatic play and dancing to represent the life and growth of plants, their reaction to the weather, their basic and unique functions, like photosynthesis and respiration and their symbiotic relationships.

For example, a group of students observed the symbiotic relationship between ivy and pines and dramatized this coexistence using their bodies. The members of the group commented that they did not observe any antagonistic relationship between ivy and pine trees, as it is written in scientific books, but a harmonic symbiosis.

There were also groups of students that used painting to express their thoughts and experiences from their attempt to communicate with plants. They also wrote poems to express their gratitude and recited them to the plants. Two students participating in a poem writing activity commented:

S1: "We thought that the best way of interacting with plants was to intone our poems to plants."

S2: "I think that it had a form of ritual. The way we approach it... We were all close to the plant, we read a line and then we repeated it all together. We wanted to do something for the plants that would be special."

S1: "It was the best way to send away the awkwardness we felt in the beginning and to connect with the plants."

S2: "This created a special bond with the plant."

S1: "We discussed our thoughts and feelings."

S2: "It was a beautiful experience. We wanted to have more time to devote for the interaction with the plant."

Mindfulness Techniques. There were also six groups of students that used mindfulness techniques, like meditation and yoga, to familiarise and communicate with plants. They attempted to concentrate in the "here and now" and to create interconnection with the plants. They tried to 
synchronize their breathing with the plants' breathing.

A group of students used meditation and yoga techniques to familiarize with the processes of photosynthesis, blooming and respiration, in an attempt to vegetalize their senses:

\section{"By synchronizing our body movements with the plants, we breathe clear oxygen, releasing toxins, tension and negative feelings and improving the regeneration of our cells. Plants offer us inspiration, environmental consciousness, internal peace and help us connect to our positive self. When we wake up our internal sleeping plant and use our imagination, we attempt to experience plants' processes, to let their senses affect ours, to learn to 'hear' their rhythms, their sensibility and to conceive them as allies and companions."}

Another group of students used exercises of jivamukti yoga that is based on an ecocentric view of the human/nature relationship. They thought that yoga could help them create harmonic relationships with plants and discover happiness:

"We listen to the sounds of nature and harmonize our body with the movement of plants. For a while, we leave our human nature and we take the role of the plants. We let the cool breeze drift us, the sound of their leaves, we are moving into their rhythms, we feel the relief of the water in our roots, we let the sun touch us and awake us."

...

"In the last stage of our activity we stand still, we close our eyes, we empty our mind from thoughts and meditate... We are transformed into plants. We try to keep still in a spot for ten minutes and imitate plants. At the same time we try to come closer to their sentimental world, in order to pass for a little while from the Anthropocene to the Planthroposcene."

\section{Taking Action to Ally with Plants}

One of the students' groups decided to take action. Specifically, the students used to visit a park that is near the University building. They observed that there was a lack of quantity, diversity and freedom regarding the growth of plants. Some of the parts of the park were "empty" or covered by "tidy" and "neat" grass and plants. They decided to sow seeds of flowers and herbs in a free way. They visited every day the spot to welcome the newborn creatures. They mentioned that:

\begin{abstract}
"We became friends with the plants and every time we had a meeting we knew the spot of the meeting. The plants know now our problems and we know their ones. Slowly, our company becomes bigger: ants, flies, butterflies and weeds come to us. This is a space for everyone..."
\end{abstract}

The students had first attempted to cultivate plants in the building of the University, but were disappointed to observe that there was no soil or any free place for the seeds to grow. However, through their activity in the park, they managed to pass from empathy to action, allying with the plants in the city in a free and radical way.

\section{DISCUSSION AND CONCLUSION}

Since the disenchantment of human/nature took place in the framework of modernity, human beings were cut off from the rest of nature and chose to perceive the world mainly through their mind and its extension - technoscience. The current research reveals the need to be more than passive observers and managers of the natural world in the era of the Anthropocene. There is still hope, if we decide to perform our liberation from human/nature separation and to transform the traditional anthropocentric view to radical, ecocentric praxis under the lens of human-plants synergy.

In the current study, we explored how undergraduate students / future in-service teachers reflected on the notion of the Planthroposcene and transformed the theoretical context to insight, experience and action in the framework of pedagogical praxis. The research reveals how the Planthroposcene hypothesis can inspire and create cracks to the established anthropocentric way of thinking and acting in the Anthropocene cultivating ecocentric common worlds (Latour, 2009, 2013), where humans and plants can coexist and interact. It also reveals the potential of including the context of the Planthroposcene in environmental education theory and praxis.

The research results reveal the potential of moving away from the traditional, anthropocentric approach that is still dominant in environmental learning. The students participated in a pedagogical process that was based on an ecocentric orientation. Myers' (2017, 2018) ideas on the Plantroposcene were an inspiration that helped to abandon the established anthropocentric view that approaches nature as a tool for human survival and prosperity or as an educational tool for the obtainment of 
environmental knowledge and other abilities. The notion of the Planthroposcene emerged a whole cosmos of potential for interaction and synergy with more-than-human on an equal basis.

The holistic, ecological knowledge that was cocreated with the plants empowered the sense of coexistence and empathy for the more-than-human world. The ecocentric ideas of this path encouraged the participants to reflect deeper on ecological crisis and our position on Earth. Naess (1973) has explained the limitations of the ecological thought and the potentiality of a philosophy of ecological harmony in the framework of an ecocentric deep ecology movement. It is through our ecological self and own ecophilosophy that we can essentially empower our ecological consciousness (Naess, 1988).

Myers (2017) suggests that, if the Anthropocene has been marked by the extractive and destructive powers of capitalism and colonialism, we should get ourselves out from under its shadow. The research attempts to contribute to this direction in the framework of pedagogical research and practice. How could environmental education programs be designed and implemented away from the Anthropocene, the greening of economy and society and the established sustainability rhetoric? And how could ecocentric ideas be combined with holistic, experiential environmental education?

The current educational process emphasized students' encounters with plants though their body and its senses. The participants activated the unused canals of their sensory perception and they were open to feel and sense the otherness of plant-being (Abram, 1997; Aloi, 2018). They also practiced their biophilic relationship with plants through an embodied approach (Pulkki, Dahlin, \& Varri, 2017). Because "it is through our bodies that we may find within ourselves our source within nature. Through our bodies, we find ourselves to be nature" (Witteman, 2020, 75).

The participants achieved to empower their ecological consciousness through an experiential and holistic pedagogical process, away from cognitive learning. They succeeded to approach plants, not through science-based schemes, but by energising their living body and by opening its inactive canals of senses. It is through the exploration and reflection on our body the ability to obtain a holistic knowledge of the Earth (Nazir \& Pedretti, 2016; Payne, 1997; Tsevreni, 2021; Witteman, 2020).

In this case study, the combination of ecocentrism with a holistic approach of environmental education revealed various possibilities for future radical pedagogical research and praxis. The current research project encouraged the students / future in service teachers in early childhood environmental education to connect with plants. The bond that was created included communication, sensorial and embodied interaction, cultivation of empathy and agency for the world of plants. It created the foundations for an ecocentric consciousness and for a human-plants synergy.

However, the current study has the limitations of a qualitative research that is implemented with the engagement of a small number of participants. Further research is needed to explore the pedagogical approach of the Planthroposcene with more groups of participants of several levels and ages. Furthermore, it would be valuable to investigate how this liberating and empowering ecocentric pedagogical philosophy and methodology could be applied in the framework of early childhood environmental education, which has been a pioneer in the recent tend of paradigm shift, from humancentric learning about the environment to learning to become with in our common worlds (Common Worlds Research Collective, 2020; Somerville, 2019; Taylor \& Giugni, 2012). Early childhood environmental education, which has been growing and flourishing as a promising field aiming at cultivating young children's appreciation and interconnection with the natural world (Carson, 1956; Wilson 1993), seems to be an ideal field for introducing radical, ecocentric ideas for being, learning and flourishing together in the world and cultivate synergy with the more-than-human. The inclusion of the Planthroposcene in design and implementation of environmental education programs for young children may emerge liveable worlds of ecocentric possibilities.

\section{ACKNOWLEDGEMENTS}

I would like to thank the students of the "Empowering children-nature relationship" course for their devotion and enthusiasm. Their work has been an inspiration.

\section{REFERENCES}

Abram, D. (1997). The spell of the sensuous: perception and language in a more-than-human world. New York: Vintage Books.

Aloi, G. (ed.) (2018). Why look at plants? The botanical emergence in contemporary art. Boston: Brill.

Bonnett, M. (2007). Environmental education and the issue of nature. Journal of Curriculum Studies, 39(6), 707-721.

https://doi.org/10.1080/00220270701447149

Boyatzis, R. E. (1998). Transforming qualitative information: thematic analysis and code development. London: Sage. 
Braun, V., \& V. Clarke (2006). Using thematic analysis in psychology. Qualitative Research in Psychology, 3(2), 77-101. https://doi.org/10.1191/1478088706qp063oa

Carson, R. (1956). Help your child to wonder. Companion, July, 24-27/46-48.

Common Worlds Research Collective, (2020). Learning to become with the world: Education for future survival. Paper commissioned for the UNESCO Futures of Education report (forthcoming, 2021).

Crutzen, P. (2002). Geology of mankind. Nature, 415, 23. https://doi.org/10.1038/415023a

Hall, M. (2011). Plants as persons. A philosophical botany. Albany: SUNY Press.

Haraway, D. (2008) When Species Meet. Minneapolis: University of Minnesota Press.

Haraway, D. (2016). Staying with the trouble: Making kin in the Chthulucene. Durham, NC: Duke University Press.

Latour, B. (2004). Politics of nature: how to bring the sciences into democracy. Cambridge, MA: Harvard University Press.

Latour, B. (2009). A collective of humans and non humans: Following Daedalus's labyrinth. In D. M. Kaplan (Ed.), Reading in the philosophy of technology (pp. 156-172). Plymouth, UK: Rowman \& Littlefield.

Latour, B. (2013). An inquiry into modes of existence. An anthropology of the moderns. Cambridge, MA: Harvard University Press.

Marder, M. (2013). Plant-thinking: a philosophy of vegetal life. New York: Columbia University Press.

Marder, M. (2014). The philosopher's plant: an intellectual herbarium. New York: Columbia University Press.

Mitman, G. (2019). Reflections on the Plantationocene: A Conversation with Donna Haraway and Anna Tsing. https://edgeeffects.net/haraway-tsingplantationocene/

Moore, J. (Ed.) (2016). Anthropocene or Capitalocene? Nature, history, and the crisis of capitalism. Oakland, CA: PM Press.

Morton, T. (2017). Humankind: solidarity with nonhuman people. London, Brooklyn, NY: Verso.

Myers, N. (2015). Conversations on plant sensing: Notes from the field. NatureCulture, 3, 35-66. https://doi.org/10.18910/75519

Myers, N. (2017). From the Anthropocene to the Planthroposcene: designing gardens for plant/people involution. History and Anthropology, 28(3), 297-301.

https://doi.org/10.1080/02757206.2017.1289934

Myers, N. (2018). How to grow livable worlds: Ten notso-easy steps. In K. O. Smith (ed.), The World to Come (pp. 53-63). Gainsville, Florida: Harn Museum of Art.

Naess, A., Drengson, A. R., \& Devall, B. (2008). Ecology of wisdom: Writings by Arne Naess. Berkeley, CA: Counterpoint.
Naess, A. (1973). The shallow and the deep, long range ecology movement. A summary, Inquiry, 16(1-4), 95-100. https://doi.org/10.1080/00201747308601682

Naess, A. (1988). Selfrealization: An ecological approach to being in the world. In J. Seed, J. Macy, P. Fleming \& A. Naess, Thinking like a Mountain. Towards a Council of All Beings (pp. 19-30). Philadelphia, PA: New Society Publishers.

Nazir, J. \& Pedretti, E. (2016). Educators' perceptions of bringing students to environmental consciousness through engaging outdoor experiences. Environmental Education Research, 22(2), 288-304. https://doi.org/10.1080/13504622.2014.996208

Orr, D. W. (1994). Earth in mind. On education, environment, and the human prospect. Washington, DC: Island Press.

Payne, P. (1997). Embodiment and environmental education. Environmental Education Research, 3(2), 133-153. https://doi.org/10.1080/1350462970030203

Plumwood, V. (2002). Environmental culture: The ecological crisis of reason. London: Routledge.

Pulkki, J., Dahlin, B., \& Varri, V.-M. (2017). Environmental education as a lived-body practice? A contemplative pedagogy perspective. Journal of Philosophy of Education, 51(1), 214-229. https://doi.org/10.1111/1467-9752.12209

Sitka-Sage, M. D., Kopnina, H., Blenkinsop, S., \& Piersol, L. (2018). Rewilding education in troubled times; or, getting back to the wrong post-nature. Visions for Sustainability, 8, 20-37. https://doi.org/10.13135/2384-8677/2334

Somerville, M. (2019). Posthuman theory and practice in early years learning. In A. Cutter-MackenzieKnowles, K. Malone, \& E. Barratt Hacking (Eds.), Research Handbook on Childhoodnature: Assemblages of Childhood and Nature Research (pp. 1-25). International Handbooks of Education. Springer, Cham.

Taylor, A., \& Giugni, M. (2012). Common worlds: Reconceptualising inclusion in early childhood communities. Contemporary Issues in Early Childhood, 13(2), 108-120.

https://doi.org/10.2304/ciec.2012.13.2.108

Tsing, A. (2012). Contaminated diversity in 'slow disturbance': Potential collaborators for a liveable earth. In G. Martin, D. Mincyte, \& U. Münster (Eds.), Why do we value diversity? Biocultural Diversity in a Global Context, RCC Perspectives 9, 95-97.

Tsevreni, I. (2021). Nature journaling as a holistic pedagogical experience with the more-than-human world. The Journal of Environmental Education, 52(1), 14-24. https://doi.org/10.1080/00958964.2020.1724854

Tsing, A, (2015). The mushroom at the end of the world: on the possibility of life in capitalist ruins. Princeton, Oxford: Princeton University Press. 
Wilson, E. O. (1984). Biophilia. Massachusetts: Harvard University Press.

Wilson. R. A. (1993). Fostering a sense of wonder during the early childhood years. Greyden Press.

Witteman, C. M. (2020). Body as prism: somatic pedagogy in the development of embodied ecological awareness. Canadian Journal of Environmental Education, 23(3), 74-91.

Wohlleben, P. \& Flanery, T. (2016). The hidden life of trees: what they feel, how they communicatediscoveries from a secret world. Vancouver: Greystone Books.

Wolfe, C. (2010). What is posthumanism? Minneapolis: University of Minnesota Press. 